Full Paper

\title{
Voltammetric Behavior of Antileukemia Drug Glivec. Part I - Electrochemical Study of Glivec
}

\author{
Victor Constantin Diculescu, ${ }^{\mathrm{a}}$ Marilene Vivan, ${ }^{\mathrm{b}}$ Ana Maria Oliveira Brett ${ }^{\mathrm{a} *}$ \\ a Departamento de Química, Faculdade de Ciências e Tecnologia, Universidade de Coimbra, 3004-535 Coimbra, Portugal \\ b Hospital da Universidade de Coimbra, 3000 Coimbra, Portugal \\ *e-mail: brett@ci.uc.pt
}

Received: May 18, 2006

Accepted: June 28, 2006

\begin{abstract}
The electrochemical behavior of the antileukemia drug glivec was investigated at a glassy carbon electrode (GCE). The oxidation is a complex, $\mathrm{pH}$-dependent, irreversible electrode process involving the transfer of 2 electrons and 2 protons and the formation of an electroactive product, $\mathrm{P}_{\text {glivec }}$, which strongly adsorbs on the GCE surface and undergoes reversible oxidation. The adsorption of $P_{\text {glivec }}$ at the GCE surface yields a compact monolayer that inhibits further oxidation of glivec. The electrochemical reduction is a simple $\mathrm{pH}$ dependent irreversible process involving the transfer of 2 electrons and 2 protons and occurs with the formation of a nonelectroactive product. The diffusion coefficient of glivec was calculated to be $D_{\mathrm{O}}=7.35 \times 10^{-6} \mathrm{~cm}^{2} \mathrm{~s}^{-1}$ in $\mathrm{pH} 4.50 .1 \mathrm{M}$ acetate buffer.
\end{abstract}

Keywords: Glivec, Chronic myelogenous leukemia (CML), Electrochemistry, Voltammetry, Adsorption

DOI: 10.1002/elan.200603591

\section{Introduction}

Protein kinases form a major class of enzymes that play an important role in signal transduction pathways, regulating a number of cellular functions such as cell growth, differentiation and cell death [1]. For this reason, protein tyrosine kinases became attractive targets in the research for therapeutic agents, not only against cancer but also against many other diseases [1 -3]. In recent years, different types of tyrosine kinase inhibitors have been described and reviewed [4]. Although most of these drugs served as tools to set up in vivo assay systems and to prove their functionality, only a few demonstrated in vivo efficacy.

Glivec (Gleevec, STI 571, or imatinib mesylate) [5], Scheme 1 , one of the most potent in vitro and in vivo inhibitor of ABL-kinase, the center to the pathogenesis of chronic myelogenous leukemia (CML), is a recently developed drug that belongs to the 2-phenylaminopyrimidine<smiles>CO[SH](=O)(O)c1ccc(CN2CCN(C)CC2)cc1</smiles>

Scheme 1. Glivec chemical structure.

Electroanalysis 18, 2006, No. 18, 1800-1807 class $[5,6]$. Glivec acts specifically by blocking the binding site for ATP in the ABL-kinase [7]. This inhibits the ability of ABL to transfer phosphate groups from ATP and phosphorylate tyrosine residues on substrate proteins, which in turn prevents the transduction of energy signals necessary for ABL-induced cellular proliferation and apoptosis [8]. Based on its activity on CML, glivec is undergoing extensive investigation for its activity against other tumor types $[9,10]$.

As already mentioned, glivec has been screened to target tyrosine kinases but, recently, using an alkaline comet assay it was shown that glivec also induces DNA damage in human leukemic cells expressing the $B C R-A B L$ protein [11]. In these studies, glivec did not induce DNA strand breaks in the direct interaction with DNA but rather alkali-labile sites. Moreover, the pretreatment of the $B C R-A B L$ protein expressing cells with vitamins $\mathrm{A}, \mathrm{C}$ and $\mathrm{E}$ reduced the extent of DNA damage caused by glivec. However, as a main result, the mechanism of the antileukemic action of glivec may involve not only the inhibition of $B C R-A B L$, but also DNA damage in the cells expressing this fusion protein.

Although glivec has proven to be a highly promising treatment for CML, the patients showing significant hematological and cytogenetical responses, resistance to glivec is still a problem mainly in patients in the accelerated or blast crisis phases of the disease $[12,13]$. Whereas responses have been durable in patients in the chronic phase, blast crisis patients quite often undergo relapse. Also, it has been shown that specific mutations within the kinase domain are a primary cause of glivec resistance. The main way to overcome this is a combination therapy with other drugs [14]. 
Being a relatively new drug, there are only a few references about glivec reactions mechanism in the specialized literature. Most deal with the analytical detection of glivec and its main metabolite in urine or human plasma and are based on liquid chromatography tandem mass spectrometry [15-19], capillary zone electrophoresis [20] and more recently on voltammetric methods [21].

Due to their high sensitivity, voltammetric methods have been successfully used for the detection and determination of various biological compounds [22-25]. Besides the analytical goals, investigations of the redox behavior of different compounds by means of electrochemical techniques have the potential for providing valuable insights into the redox reactions of these molecules.

Therefore, the present study is concerned with the investigation of the electron transfer properties of glivec using cyclic, differential pulse and square-wave voltammetry and a glassy carbon electrode. The investigation of the electrochemical oxidation and reduction mechanisms of glivec is important since this could result in a better understanding of the data already known [21] and increase the overall knowledge of glivec's physiological mechanisms of action.

\section{Experimental}

\subsection{Materials and Reagents}

Glivec capsules of $100 \mathrm{mg}$ obtained from Novartis (Portugal), were used without further purification. Stock solutions of $100 \mu \mathrm{M}$ were prepared in purified water and stored at $-4{ }^{\circ} \mathrm{C}$. Solutions of different concentrations of glivec were prepared by dilution of the appropriate quantity in supporting electrolyte.

All supporting electrolyte solutions, Table 1, were prepared using analytical grade reagents and purified water from a Millipore Milli-Q system (conductivity $\leq 0.1 \mu \mathrm{S}$ $\left.\mathrm{cm}^{-1}\right)$.

Microvolumes were measured using EP-10 and EP-100 Plus Motorized Microliter Pippettes (Rainin Instrument Co. Inc., Woburn, USA). The $\mathrm{pH}$ measurements were carried out with a Crison micropH 2001 pH-meter with an Ingold combined glass electrode. All experiments were done at room temperature $\left(25 \pm 1^{\circ} \mathrm{C}\right)$.

Table 1. Supporting electrolytes, $0.1 \mathrm{M}$ ionic strength.

\begin{tabular}{ll}
\hline $\mathrm{pH}$ & Composition \\
\hline 2.6 & $\mathrm{HCl}+\mathrm{KCl}$ \\
3.8 & $\mathrm{HAcO}+\mathrm{NaAcO}$ \\
4.5 & $\mathrm{HAcO}+\mathrm{NaAcO}$ \\
5.5 & $\mathrm{HAcO}+\mathrm{NaAcO}$ \\
6.2 & $\mathrm{NaH}_{2} \mathrm{PO}_{4}+\mathrm{Na}_{2} \mathrm{HPO}_{4}$ \\
7 & $\mathrm{NaH}_{2} \mathrm{PO}_{4}+\mathrm{Na}_{2} \mathrm{HPO}_{4}$ \\
8.2 & $\mathrm{NaH}_{2} \mathrm{PO}_{4}+\mathrm{Na}_{2} \mathrm{HPO}_{4}$ \\
9.1 & $\mathrm{NaOH}+\mathrm{Na}_{2} \mathrm{~B}_{2} \mathrm{O}_{7}$ \\
12 & $\mathrm{NaOH}+\mathrm{KCl}$ \\
\hline
\end{tabular}

\subsection{Voltammetric Parameters and Electrochemical Cells}

Voltammetric experiments were carried out using a $\mu$ Autolab running with GPES 4.9 software, Eco-Chemie, Utrecht, The Netherlands. The experimental conditions for differential pulse voltammetry (DPV) were: pulse amplitude $50 \mathrm{mV}$, pulse width $70 \mathrm{~ms}$, scan rate $5 \mathrm{mV} \mathrm{s}^{-1}$. Measurements were carried out using a glassy carbon electrode $(\mathrm{GCE})(d=$ $1.5 \mathrm{~mm})$, with a $\mathrm{Pt}$ wire counter electrode, and a $\mathrm{Ag} / \mathrm{AgCl}$ $(3 \mathrm{M} \mathrm{KCl})$ electrode as reference, in a $0.5 \mathrm{~mL}$ one-compartment electrochemical cell.

The GCE was polished using diamond spray (particle size $1 \mu \mathrm{m}$ ) before every electrochemical assay. After polishing, the electrode was rinsed thoroughly with Milli-Q water for $30 \mathrm{~s}$; then it was sonicated for 1 minute in an ultrasound bath and again rinsed with water. After this mechanical treatment, the GCE was placed in buffer electrolyte and various DP voltammograms were recorded until a steady state baseline voltammogram was obtained. This procedure ensured very reproducible experimental results.

\subsection{Acquisition and Presentation of Voltammetric Data}

All the voltammograms presented were background-subtracted and baseline-corrected using the moving average application with a step window of $5 \mathrm{mV}$ included in GPES version 4.9 software. This mathematical treatment improves the visualization and identification of peaks over the baseline without introducing any artifact, although the peak intensity is in some cases reduced $(<10 \%)$ relative to that of the untreated curve. Nevertheless, this mathematical treatment of the original voltammograms was used in the presentation of all experimental voltammograms for a better and clearer identification of the peaks. The values for peak current presented in all plots were determined from the original untreated voltammograms after subtraction of the base line.

\section{Results and Discussion}

Initial studies concerning the voltammetric behavior of glivec at a GCE were carried out in $\mathrm{pH} 4.50 .1 \mathrm{M}$ acetate buffer. The cyclic voltammograms, Figure 1, were obtained in a solution of $50 \mu \mathrm{M}$ glivec saturated with $\mathrm{N}_{2}$. During the voltammetric measurement a constant flux of $\mathrm{N}_{2}$ was kept over the solution surface in order to avoid the diffusion of atmospheric oxygen into the solution of glivec.

Several peaks can be observed in Figure 1. The reduction and oxidation of glivec occur independently of each other and were investigated separately. 


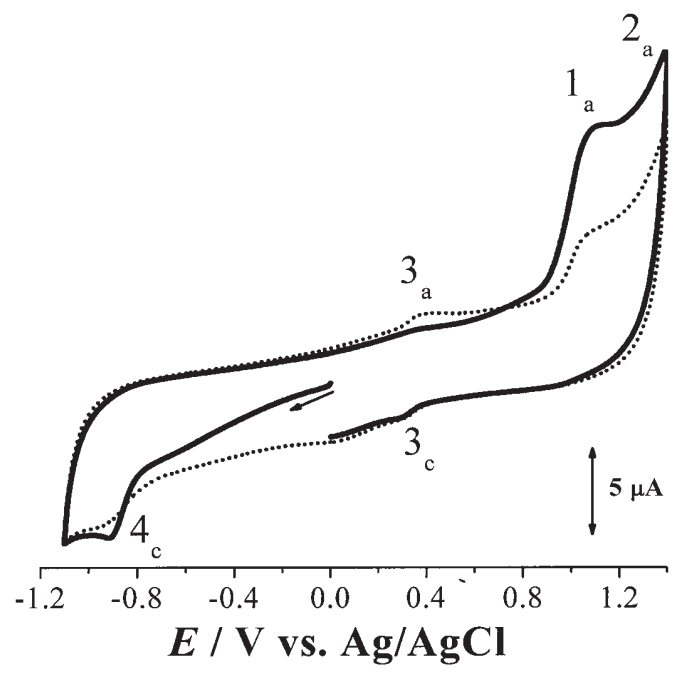

Fig. 1. CV obtained with a GCE in a solution of $50 \mu \mathrm{M}$ glivec in $\mathrm{pH}$ 4.5 $0.1 \mathrm{M}$ acetate buffer saturated with $\mathrm{N}_{2} ;(-) 1^{\text {st }}$ and $(\cdots . .$. $2^{\text {nd }}$ scan at $v=500 \mathrm{mV} \mathrm{s}^{-1}$.

A

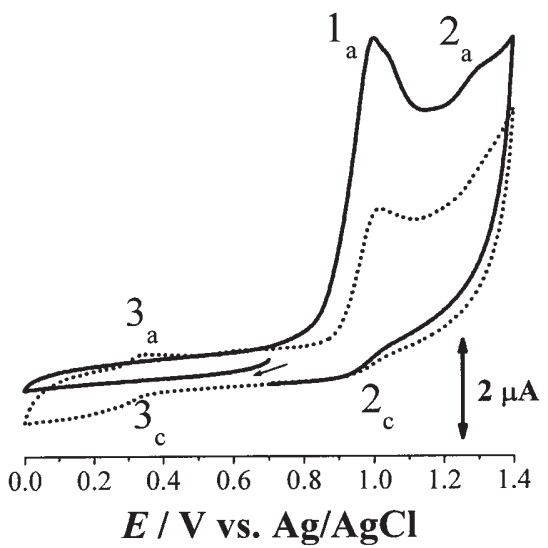

$\mathrm{C}$

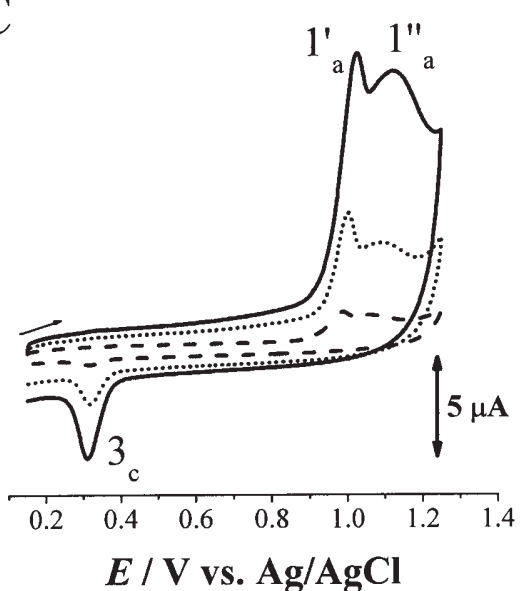

\subsection{Oxidation}

\subsubsection{Cyclic Voltammetry}

The oxidation of glivec at a GCE was first studied in $\mathrm{pH} 4.5$ $0.1 \mathrm{M}$ acetate buffer. The $\mathrm{CV}$ obtained in a $50 \mu \mathrm{M}$ glivec solution at a scan rate of $v=100 \mathrm{mV} \mathrm{s}^{-1}$, Figure $2 \mathrm{~A}$, shows two anodic peaks at $E_{\mathrm{pa}}^{1}=+1.00 \mathrm{~V}$, peak $1_{\mathrm{a}}$ and at $E_{\mathrm{pa}}^{2}=$ $+1.25 \mathrm{~V}$, peak $2_{\mathrm{a}}$. On the negative-going scan, two reduction peaks occurred at $E_{\mathrm{pc}}^{2}=+0.96 \mathrm{~V}$, peak $2_{\mathrm{c}}$ and at $E_{\mathrm{pc}}^{3}=$ $+0.28 \mathrm{~V}$, peak $3_{\mathrm{c}}$ respectively. These cathodic peaks correspond to the reduction of the glivec oxidation products formed at the GCE surface. A subsequent CV scan showed a new oxidation peak $3_{\mathrm{a}}$ at $E_{\mathrm{pa}}^{3}=+0.34 \mathrm{~V}$. At the same time, a decrease of peaks $1_{\mathrm{a}}$ and $2_{\mathrm{a}}$ was also observed due to the adsorption of glivec and/or its oxidation product on the GCE surface.

In a new experiment, using a clean GCE, the scan direction was inverted immediately after peak $1_{\mathrm{a}}$ and before peak $2_{\mathrm{a}}$. On the negative going scan, only peak $3_{\mathrm{c}}$ appeared at $E_{\mathrm{pc}}^{3}=+0.28 \mathrm{~V}$, Figure 2B. Thus, peak $3_{\mathrm{c}}$ corresponds to the reduction of the species formed at the GCE surface after

B

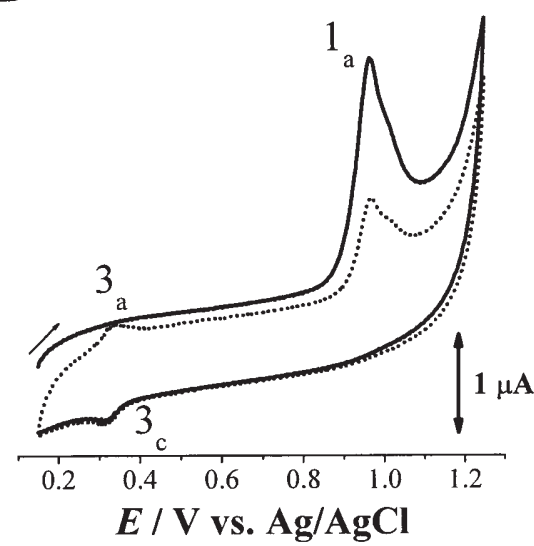

$\mathrm{D}$

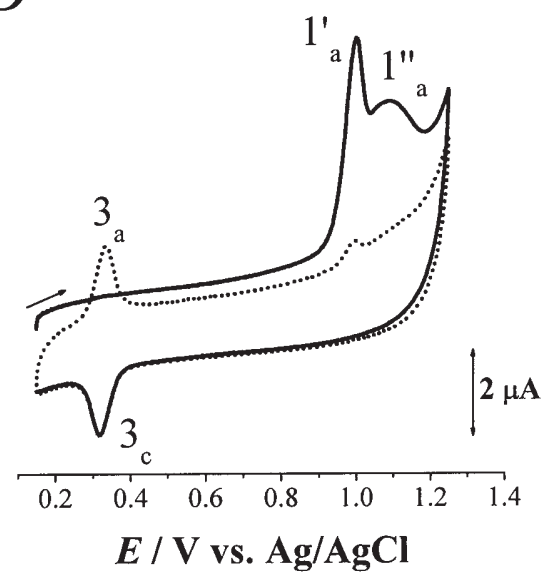

Fig. 2. CVs obtained with a GCE in a solution of: A) $50 \mu \mathrm{M}$ glivec, $(-) 1^{\text {st }}$ and $(\cdots \cdots ..) 2^{\text {nd }}$ scan at $\left.v=0.10 \mathrm{~V} \mathrm{~s}^{-1} ; \mathrm{B}\right) 10 \mu \mathrm{M} \mathrm{glivec},(-) 1^{\text {st }}$ and $(\cdots \cdots) 2^{\text {nd }}$ scan at $\left.v=0.10 \mathrm{~V} \mathrm{~s}^{-1}, \mathrm{C}\right) 1^{\text {st }}$ scan at $(---) 0.40,(\cdots \cdots) 0.75$, and $\left.(-) 1.50 \mathrm{~V} \mathrm{~s}^{-1}, \mathrm{D}\right)(-) 1^{\text {st }}$ and $(\cdots \cdots) 2^{\text {nd }}$ scan at $v=$ $1.00 \mathrm{~V} \mathrm{~s}^{-1}$ in $\mathrm{pH} 4.30 .1 \mathrm{M}$ acetate buffer.

Electroanalysis 18, 2006, No. 18, 1800-1807 www.electroanalysis.wiley-vch.de @ 2006 WILEY-VCH Verlag GmbH\& Co. KGaA, Weinheim 
glivec oxidation at $E_{\mathrm{pa}}^{1}=+1.00 \mathrm{~V}$, peak $1_{\mathrm{a}}$. This glivec oxidation product will be designated as $\mathrm{P}_{\text {glivec }}$. Moreover, peak $3_{\mathrm{a}}$ occurs on a subsequent $\mathrm{CV}$ scan at $E_{\mathrm{pa}}^{3}=+0.34 \mathrm{~V}$, the $E_{\mathrm{pa}}^{3}-E_{\mathrm{pc}}^{3}=0.06 \mathrm{~V}$ denoting a reversible couple corresponding to adsorbed $\mathrm{P}_{\text {glivec }}$ reaction. The big decrease of peak $1_{a}$ is due to the strong adsorption of $P_{\text {glivec }}$ at the GCE surface, that reduces the available electrode surface area.

Also, in the above described experiment, peak $2_{\mathrm{c}}$ does not occur, Figure 2B, showing that this peak corresponds to the species oxidized at $E_{\mathrm{pa}}{ }^{2}=+1.25 \mathrm{~V}$.

$\mathrm{CVs}$ were obtained for different scan rates in a solution of $10 \mu \mathrm{M}$ glivec in $\mathrm{pH} 4.50 .1 \mathrm{M}$ acetate buffer always using a clean GCE surface. Peak $1_{\mathrm{a}}$ becomes broader on increasing the scan rate, and for $v>200 \mathrm{mV} \mathrm{s}^{-1}$ two peaks occur, Figure $2 \mathrm{C}$. The first narrow high peak $1_{\mathrm{a}}^{\prime}$ appears at a lower potential followed by a smaller and broader peak $1_{\mathrm{a}}^{\prime \prime}$.

The above result can be explained taking into account the hindering of the oxidation reaction of glivec as a consequence of electrode surface blockage due to the adsorption of the glivec oxidation product, peak $3_{\mathrm{a}}, \mathrm{P}_{\text {glivec }}$ [26]. Glivec molecules in close proximity to the electrode surface are oxidized giving rise to peak $1_{\mathrm{a}}^{\prime}$ and to $\mathrm{P}_{\text {glivec }}$ that remains adsorbed on the GCE surface forming a noncompact monolayer. Further oxidation of glivec molecules diffusing from the bulk solution towards the electrode, peak $1_{\mathrm{a}}^{\prime \prime}$, is more difficult because it occurs through the layer of adsorbed $\mathrm{P}_{\text {glivec }}$. However, after the process corresponding to peak $1_{\mathrm{a}}^{\prime \prime}$ the layer of $\mathrm{P}_{\text {glivec }}$ becomes more compact covering the electrode surface and impeding further oxidation of glivec molecules that diffuse from the solution. This is also confirmed by the considerable decrease of peak $1_{\mathrm{a}}^{\prime}$ and disappearance of peak $1_{\mathrm{a}}^{\prime \prime}$ observed on the second scan, Figure 2D.

The reduction peak $3_{\mathrm{c}}$ always appeared on the negativegoing scans and the current increases with increasing scan rate, Figure 2C. Also, the anodic peak $3_{\mathrm{a}}$ was always obtained by recording consecutive voltammograms in the same solution, forming a reversible couple with peak $3_{c}$, Figure $2 \mathrm{D}$. At the same time, peaks $1_{\mathrm{a}}^{\prime}$ and $1_{\mathrm{a}}^{\prime \prime}$ were considerably diminished.

The effect of the scan rate on the current and potential of peak $1_{\mathrm{a}}$ was also investigated (not shown). Cyclic voltammograms were sequentially recorded for $5 \leq v \leq 2000 \mathrm{mV} \mathrm{s}^{-1}$ in $\mathrm{pH} 4.50 .1 \mathrm{M}$ acetate buffer containing $10 \mu \mathrm{M}$ glivec always using a freshly polished electrode surface.

A linear dependence of peak current $1_{\mathrm{a}}$ with square root of scan rate $\left(v^{1 / 2}\right)$ was observed for $5 \leq v \leq 200 \mathrm{mV} \mathrm{s}^{-1}$. For higher scan rates, deviation from linearity was obtained due to the adsorption of $\mathrm{P}_{\text {glivec }}$ at the GCE surface [27].

The peak $1_{\mathrm{a}}$ potential varies linearly with the logarithm of the scan rate changing by $31 \mathrm{mV}$ per decade for $5 \leq v \leq$ $200 \mathrm{mV} \mathrm{s}^{-1}$, showing that the glivec oxidation reaction is diffusion-controlled. For higher scan rates, peak $1_{\mathrm{a}}$ became more positive with increasing scan rate and the slope of the linear variation changed to $71 \mathrm{mV}$ per decade. This change of the slope indicates that the reaction passes gradually from a diffusion-controlled process to a surface reaction on increasing the scan rate [27].

\subsubsection{Differential Pulse Voltammetry}

The electrochemical oxidation of glivec was studied over a wide $\mathrm{pH}$ range between 2 and 13 using DPV. The DP voltammograms, Figure 3A, were all recorded in solutions of $5 \mu \mathrm{M}$ glivec in different electrolytes of $0.1 \mathrm{M}$ ionic strength.

In very acidic media $(\mathrm{pH}<2)$, no oxidation peak for glivec was observed and only at $\mathrm{pH} 2.6$ and 9.2 both peaks $1_{\mathrm{a}}^{\prime}$ and $1_{\mathrm{a}}^{\prime \prime}$ were seen, Figure 3A.

The variation of $E_{\mathrm{pa}}$ with the electrolyte $\mathrm{pH}$ obtained always in a solution of $5 \mu \mathrm{M}$ glivec, shows that the peak $1_{\mathrm{a}}$ and $2_{a}$ potentials are displaced to less positive values by increasing the $\mathrm{pH}$ of the supporting electrolyte, Figure 3A. Peak $1_{\mathrm{a}}$ potential follows a linear relationship with $\mathrm{pH}$ and the slope of the line is $59 \mathrm{mV}$ per $\mathrm{pH}$ unit, Figure 3B, which shows that the oxidation mechanism of glivec involves the same number of electrons and protons. Nevertheless, in all electrolytes, the width at half height of the glivec oxidation peak $1_{\mathrm{a}}$ was $W_{1 / 2}=55 \mathrm{mV}$, which suggests that the oxidation of glivec occurs with the transfer of 2 electrons, hence also 2 protons.
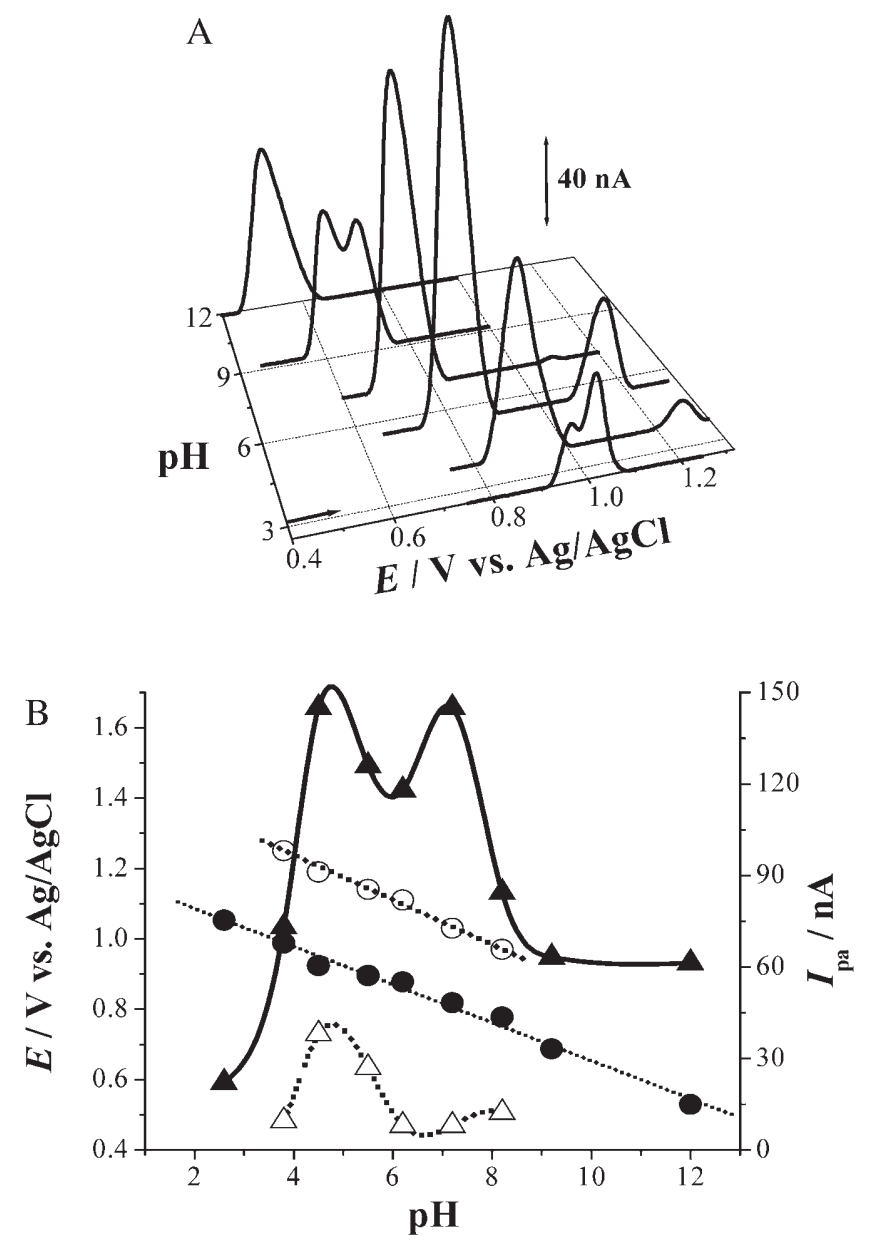

Fig. 3. A) $3 \mathrm{D}$ plot of DPV obtained in $5 \mu \mathrm{M}$ glivec as function of pH. B) Plot of $(\bullet) E_{\mathrm{pa}}$ and $(\boldsymbol{\Delta}) I_{\mathrm{pa}}$ of peak $1_{\mathrm{a}}$ and of $(\circ) E_{\mathrm{pa}}$ and $(\triangle)$ $I_{\mathrm{pa}}$ of peak $2_{\mathrm{a}}$ vs. pH. 
On the other hand, Figure $3 \mathrm{~A}$ also shows that peak 2 a occurs only in electrolytes with $\mathrm{pH}$ between 2.6 and 9.2. The $E_{\mathrm{pa}}^{2}$ dependence on $\mathrm{pH}$ is linear, the slope of $60 \mathrm{mV}$ per $\mathrm{pH}$ unit, Figure $3 \mathrm{~B}$, showing that the glivec oxidation peak $2_{\mathrm{a}}$ also involves the same number of electrons and protons. Taking into consideration the width at half height of the oxidation peak $2_{\mathrm{a}}, W_{1 / 2}=85 \mathrm{mV}$, it was concluded that the oxidation occurs with the transfer of 1 electron, hence also 1 proton.

Figure $3 \mathrm{~B}$ also shows the variation of peaks $1_{\mathrm{a}}$ and $2_{\mathrm{a}}$ oxidation currents with the $\mathrm{pH}$ of the supporting electrolyte. For peak $1_{\mathrm{a}}$ two current maxima were observed: in $\mathrm{pH} 4.5$ $0.1 \mathrm{M}$ acetate buffer and in $\mathrm{pH} 70.1 \mathrm{M}$ phosphate buffer. Peak 2 a shows higher oxidation currents in $\mathrm{pH} 4.50 .1 \mathrm{M}$ acetate buffer. For this reason, this electrolyte was used for further investigations.

Successive DP voltammograms were also recorded in a solution of $5 \mu \mathrm{M}$ glivec in $\mathrm{pH} 4.50 .1 \mathrm{M}$ acetate buffer, Figure 4A. The oxidation of glivec, peak $1_{a}$, occurs at $E_{\mathrm{pa}}^{1}=+0.90 \mathrm{~V}$ followed by peak $2_{\mathrm{a}}$ at $E_{\mathrm{pa}}^{2}=+1.22 \mathrm{~V}$. In a second DP scan, a new peak $3_{\mathrm{a}}$ occurs at $E_{\mathrm{pa}}^{3}=+0.32 \mathrm{~V}$ and the oxidation current increases with the number of scans. This peak corresponds to oxidation of glivec oxidation product, $\mathrm{P}_{\text {glivec }}$, which is strongly adsorbed at the GCE surface. At the same time, the oxidation peaks $1_{\mathrm{a}}$ and $2_{\mathrm{a}}$ decrease gradually with the number of scans due to the decrease of the available electrode surface because of adsorption of $\mathrm{P}_{\text {glivec }}$.

The adsorption of $\mathrm{P}_{\text {glivec }}$ at the GCE surface was confirmed when after several DP scans recorded in the solution of glivec the electrode was washed with a jet of deionized water and then transferred to the supporting electrolyte. The DP voltammogram obtained in these conditions, Figure 4B, shows both the oxidation of $\mathrm{P}_{\text {glivec }}$, peak $3_{\mathrm{a}}$ and peak $1_{\mathrm{a}}$ due to the oxidation of glivec. That means glivec also adsorbs at the GCE surface. However, on a second DP scan, peak $1_{a}$ disappeared due to a complete oxidation of adsorbed glivec molecules. On the other hand, peak $3_{\text {a }}$ could still be identified with a higher current. In fact, consecutively recorded DP voltammograms in buffer showed a slow decrease of the peak $3_{\text {a }}$ oxidation current only after 15 consecutive scans in buffer.

\subsubsection{Square-Wave Voltammetry}

The advantages of square-wave voltammetry (SWV) are greater speed of analysis, lower consumption of the electroactive species in relation with DPV, and reduced problems with poisoning of the electrode surface [28]. Another greater advantage of square-wave methods is the possibility to see during only one scan if the electron transfer reaction is reversible or not. Since the current is sampled in both positive and negative-going pulses, peaks corresponding to the oxidation and reduction of the electroactive species at the electrode surface can be obtained in the same experiment. Also, SWV experiments show a higher sensitivity than DPV since much faster scan rates can be used $\left(100 \mathrm{mV} \mathrm{s}^{-1}\right.$ for SWV compared to $5 \mathrm{mV} \mathrm{s}^{-1}$ for DPV).
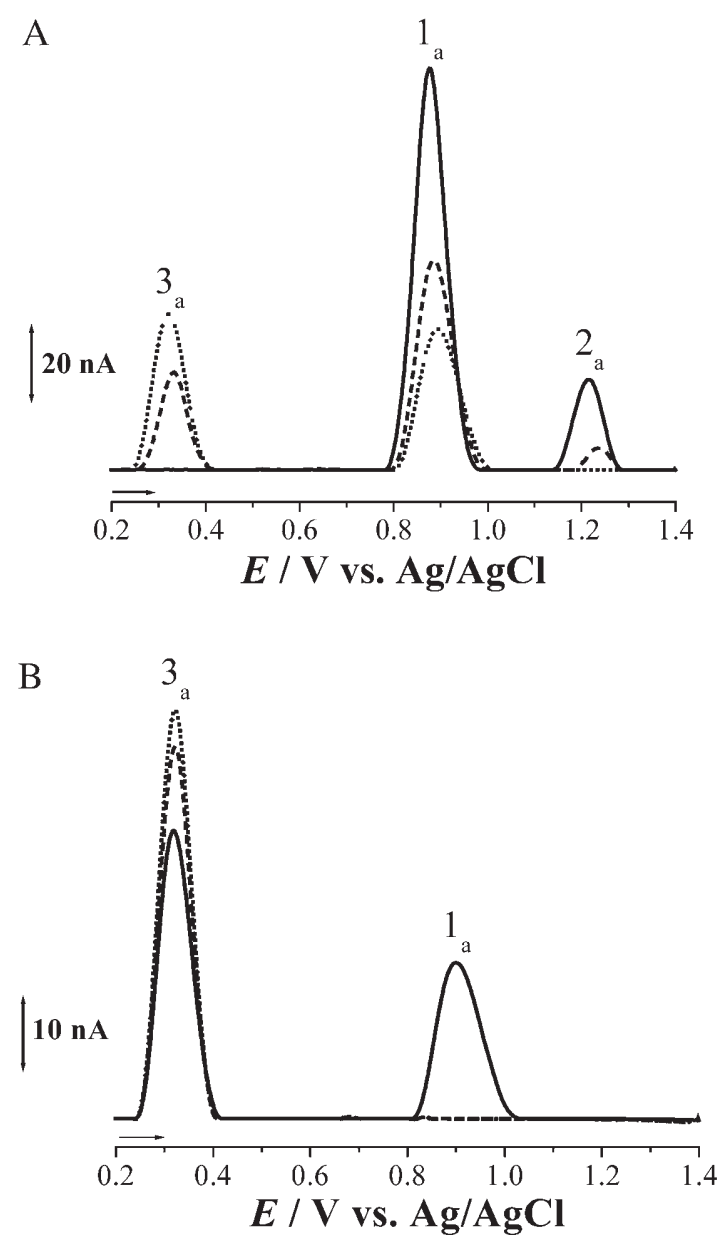

Fig. 4. DPV obtained in $\mathrm{pH} 4.30 .1 \mathrm{M}$ acetate buffer: A) (-) $1^{\text {st }}$, $(---) 2^{\text {nd }}$, and $(\cdots \cdots \cdot) 3^{\text {rd }}$ scan in $5 \mu \mathrm{M}$ glivec; B) $(-) 1^{\text {st }},(\cdots \cdots)$ $2^{\text {nd }}$, and $(---) 15^{\text {th }}$ scan after transferring to buffer. For more details see Section 3.1.2.

SWV showed similar features to CV, i.e., oxidation peaks $1_{\mathrm{a}}^{\prime}, 1_{\mathrm{a}}^{\prime \prime}$ and a strong adsorption of electrode reaction products on the second scan. The first SW scan obtained in a solution of $5 \mu \mathrm{M}$ glivec in $\mathrm{pH} 4.50 .1 \mathrm{M}$ acetate buffer, shows the narrow glivec oxidation peak $1_{\mathrm{a}}^{\prime}$ followed by a broader peak $1_{\mathrm{a}}^{\prime \prime}$ (Fig. 5A).

On a second SW scan, peak $3_{\mathrm{a}}$ occurs at $E_{\mathrm{pa}}^{2}=+0.32 \mathrm{~V}$, Figure 5B. The reversibility of peak $3_{\mathrm{a}}$ is confirmed by plotting the forward and backward components of the total current where the oxidation and the reduction currents are equal. Moreover, the identical value of the potential of peak $2_{\mathrm{a}}$ on the forward and backward current components is an indication of the adsorption of glivec oxidation products on the GCE surface [28].

\subsection{Reduction}

\subsubsection{Cyclic Voltammetry}

The reduction of glivec at a GCE was studied in $\mathrm{pH} 4.5$ $0.1 \mathrm{M}$ acetate buffer. The $\mathrm{CV}$ obtained in a $50 \mu \mathrm{M}$ glivec 

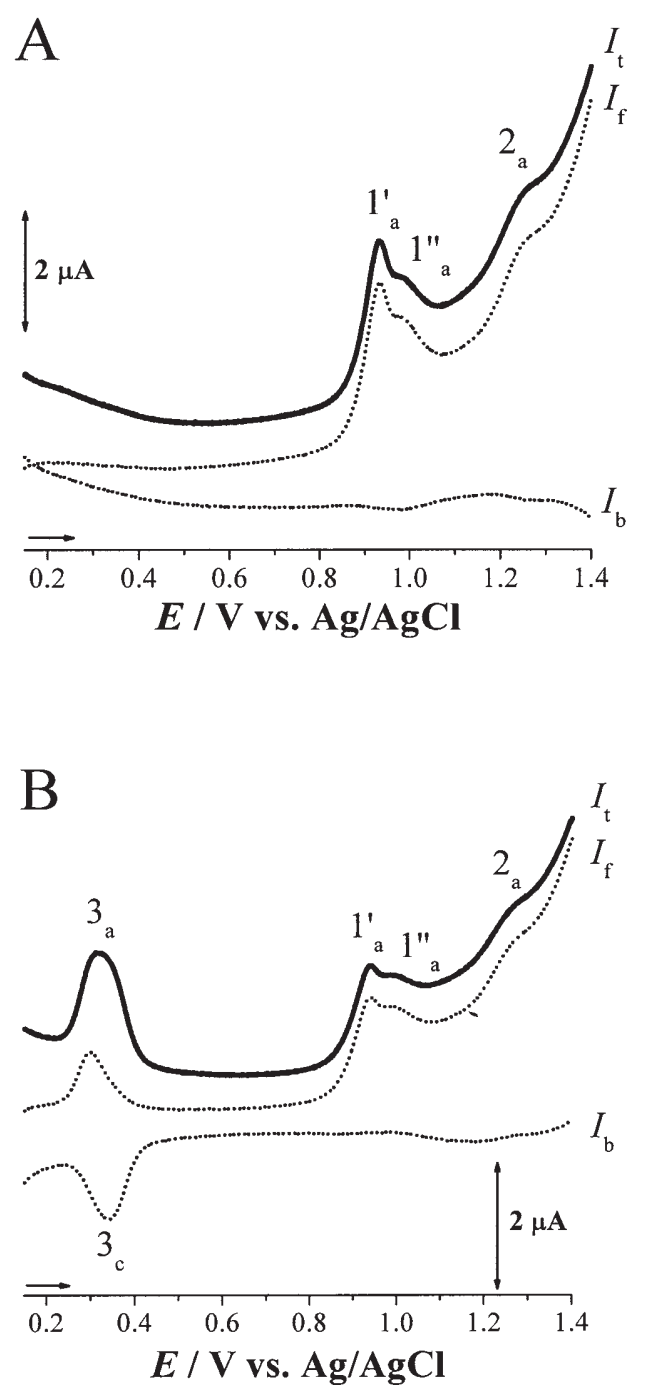

Fig. 5. SWV obtained in a solution of $5 \mu \mathrm{M}$ glivec in $\mathrm{pH}=4.3$ $0.1 \mathrm{M}$ acetate buffer: A) $1^{\text {st }}$ and B) $2^{\text {nd }} \mathrm{scan} ; f=50 \mathrm{~Hz}, \Delta E=1 \mathrm{mV}$ thus $v_{\text {effective }}=50 \mathrm{mV} \mathrm{s}^{-1}$.

solution at a scan rate $v=500 \mathrm{mV} \mathrm{s}^{-1}$, Figure 6 , shows one cathodic peak $4_{\mathrm{c}}$ that occurs at $E_{\mathrm{pa}}=-0.89 \mathrm{~V}$. On scanning in the positive direction, no oxidation peak is observed, showing that the reduction of glivec is an irreversible process and the reduction products are not electroactive. A small decrease of the reduction current occurs with the number of successive scans and is due to the adsorption of glivec reduction products on the GCE surface.

CVs were obtained for different scan rates in a solution of $50 \mu \mathrm{M}$ glivec. It was observed that, on increasing $v$, peak $4 \mathrm{c}$ potential is slightly displaced to more negative values. The dependence is linear with the decimal logarithm of the scan rate with a slope of $-26 \mathrm{mV}$ per decade. Knowing that for a diffusion-controlled irreversible system $\left|\mathrm{d} E_{\mathrm{p}} / \mathrm{d} \log v\right|=$ $29.6 /\left(\alpha_{c} n^{\prime}\right)$ where $\alpha_{c}$ is the charge transfer coefficient and $n$ ' the number of electrons in the rate-determining step [29], it can be calculated that $\alpha_{\mathrm{c}} n^{\prime}=1.1$.

Also, increasing the scan rate, the current of peak $4 \mathrm{c}$ increases linearly with the square root of $v$ (not shown),

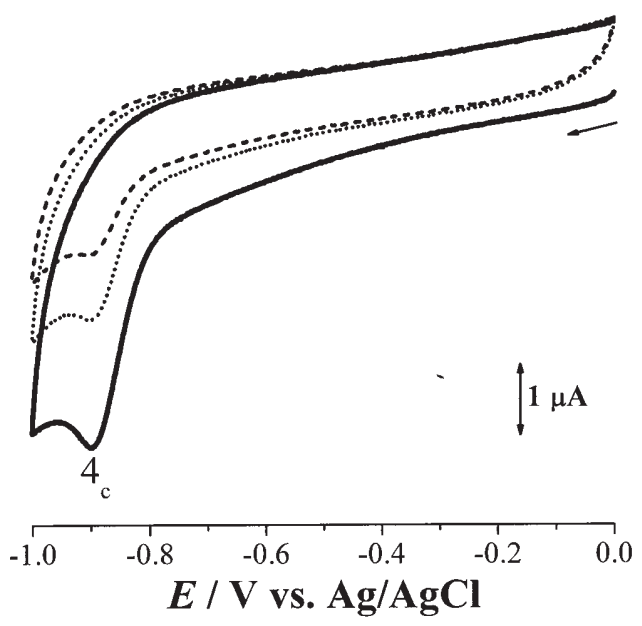

Fig. 6. $\mathrm{CV}$ obtained in $\mathrm{N}_{2}$ saturated solution of $50 \mu \mathrm{M}$ glivec pH $4.30 .1 \mathrm{M}$ acetate buffer; $(-) 1^{\text {st }},(\cdots \cdots) 2^{\text {nd }}$, and $(---) 3^{\text {rd }}$ scan at $v=500 \mathrm{mV} \mathrm{s}^{-1}$.

consistent with the diffusion-limited reduction of a solution species. The peak current in amperes for a diffusioncontrolled irreversible system is given by

$$
I_{\mathrm{pc}}(A)=-2.99 \times 10^{5} n\left(\alpha_{\mathrm{c}} n^{\prime}\right)^{1 / 2} A[\mathrm{O}]_{\infty} D_{\mathrm{O}}^{1 / 2} v^{1 / 2}
$$

where $n$ is the number of electrons transferred during the oxidation of glivec ( $n=2$ as shown below, Section 3.2.2), $A$ is the electrode area in $\mathrm{cm}^{2}, D_{\mathrm{O}}$ is the diffusion coefficient in $\mathrm{cm}^{2} \mathrm{~s}^{-1},[\mathrm{O}]_{\infty}$ is the concentration in mol cm${ }^{-3}$ and $v$ is in $\mathrm{V} \mathrm{s}^{-1}$ [29]. By plotting $I_{\mathrm{pc}}$ vs. $v^{1 / 2}$, the value of $D_{\mathrm{O}}$ is obtained. For the measured slope of $-2.59 \times 10^{-6} \mathrm{~A} /\left(\mathrm{V} \mathrm{s}^{-1}\right)^{1 / 2}$ the diffusion coefficient of glivec in $\mathrm{pH} 4.50 .1 \mathrm{M}$ phosphate buffer is $D_{\mathrm{O}}=7.2 \times 10^{-6} \mathrm{~cm}^{2} \mathrm{~s}^{-1}$. For this calculation, the GCE electroactive area was determined from a plot $I_{\mathrm{pc}}$ vs. $v^{1 / 2}$ using a solution of $0.5 \mathrm{mM}$ hexacyanoferrate and the value of the diffusion coefficient of hexacyanoferrate in phosphate buffer of $D_{\mathrm{O}}=7.35 \times 10^{-6} \mathrm{~cm}^{2} \mathrm{~s}^{-1}$ [30]. In this way, the electroactive area $0.031 \mathrm{~cm}^{2}$ was determined.

\subsubsection{Differential Pulse Voltammetry}

The electrochemical reduction of glivec was studied over a wide $\mathrm{pH}$ range between 2 and 13 using DPV. The DP voltammograms, Figure 7A, were all recorded in solutions of $50 \mu \mathrm{M}$ glivec in different electrolytes with $0.1 \mathrm{M}$ ionic strength. Only one peak $4_{c}$ occurs in all supporting electrolytes.

The peak $4_{c}$ potential is displaced to more negative values with increasing $\mathrm{pH}$. The dependence is linear over the whole $\mathrm{pH}$ range, Figure $7 \mathrm{~B}$, and follows the relationship $E_{\mathrm{pc}}(\mathrm{V})=$ $-0.51-0.061 \mathrm{pH}$. The slope of $61 \mathrm{mV}$ per $\mathrm{pH}$ unit, shows that the same number of electrons and protons is involved in the reduction mechanism of glivec. However, the width at half-height of peak $4_{c}$ was always $W_{1 / 2}=60 \mathrm{mV}$, which suggests that the reduction of glivec occurs with 2 electron transfer, hence also 2 protons. 

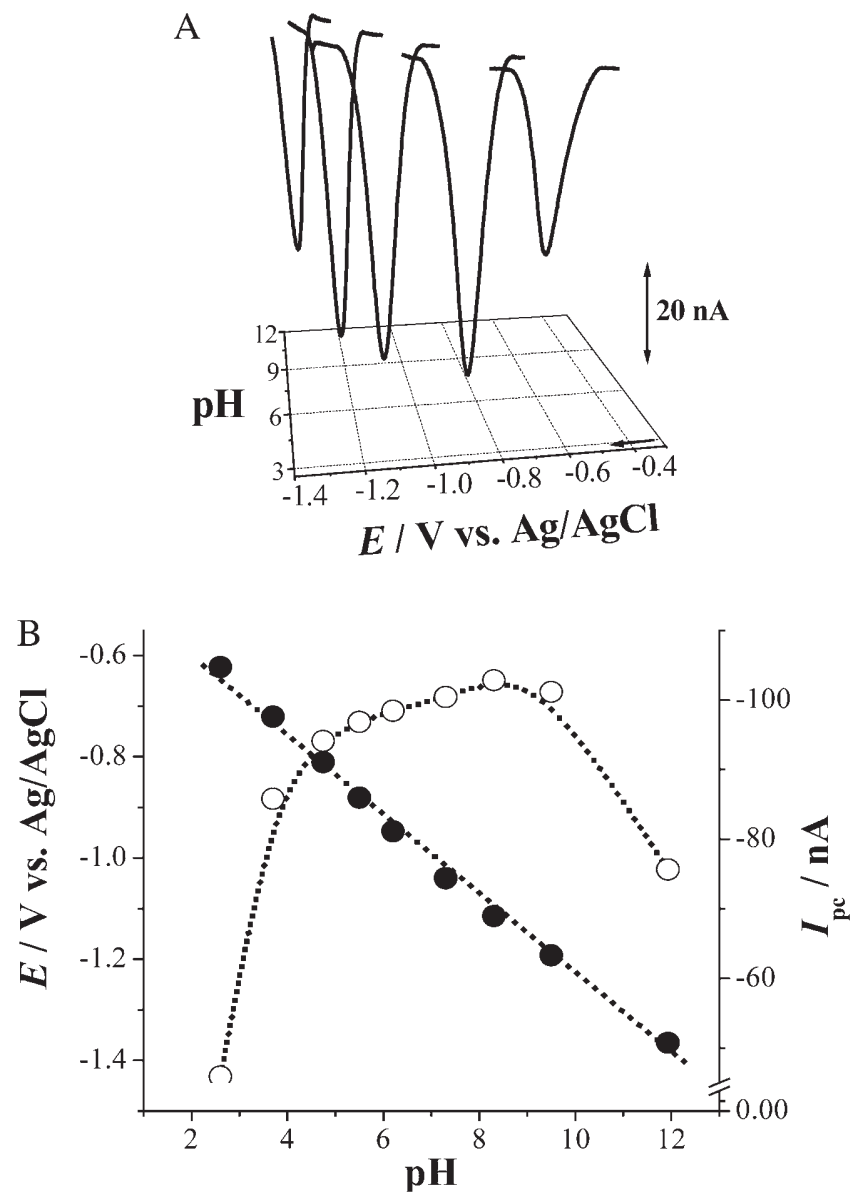

Fig. 7. A) 3D plot of DPV obtained in $50 \mu \mathrm{M}$ glivec as function of $\mathrm{pH}$. B) Plot of $(\bullet) E_{\mathrm{pc}}$ and $(\circ) I_{\mathrm{pc}}$ of peaks $4_{\mathrm{c}}$ vs. $\mathrm{pH}$.

The plot of the variation of peak $4_{\mathrm{c}}$ current versus $\mathrm{pH}$, Figure 7B, shows comparable cathodic currents for $\mathrm{pH}$ between 4 and 10 .

The results presented increase the overall understanding of the redox properties of glivec. A detailed characterization of glivec's redox behavior has been carried out allowing the determination of several important parameters, such as the number of electrons and protons involved in the redox processes of glivec and the diffusion coefficient. Nevertheless, glivec's redox mechanism can only be fully characterized when the products of electrode reaction are identified. This will only be possible using other analytical methodologies in order to identify the groups which undergo oxidation and reduction, establish the sequence of electron and proton transfer and also to characterize the products of electrode reaction.

\section{Conclusions}

The study of the redox behavior of different organic compounds using electrochemical techniques can provide valuable insights into the biological redox reactions of these molecules. Different voltammetric methods have been used to study the redox behavior of the antileukemia drug glivec, which undergoes oxidation and reduction at a glassy carbon electrode.

The oxidation of glivec is an irreversible process that occurs in cascade, two consecutive charge transfer reactions being observed. Glivec oxidation involves the formation of an oxidation product, which adsorbs strongly on the GCE surface and undergoes reversible oxidation. The formation of a compact monolayer of glivec oxidation product at the GCE surface, led to the inhibition of glivec oxidation in subsequent cyclic voltammetric scans. The oxidation of glivec is also $\mathrm{pH}$ dependent, and occurs with the transfer of 2 electrons and 2 protons.

The reduction of glivec is a simple, $\mathrm{pH}$ dependent irreversible process that proceeds with the transfer of 2 electrons and 2 protons. The diffusion coefficient of glivec was calculated to be $D_{\mathrm{O}}=7.35 \times 10^{-6} \mathrm{~cm}^{2} \mathrm{~s}^{-1}$ in $\mathrm{pH} 4.50 .1 \mathrm{M}$ acetate buffer.

\section{Acknowledgements}

Financial support from Fundação para a Ciência e Tecnologia (FCT), Post-Doctoral Grant SFRH/BPD/18824/2004 (V. C.Diculescu.), POCTI (cofinanced by the European Community Fund FEDER), and ICEMS (Research Unit 103 ) is gratefully acknowledged.

\section{References}

[1] A. Bennasroune, A. Gardin, D. Aunis, G. Crémel, P. Hubert, Crit. Rev. Oncol. Hemat. 2004, 50, 23.

[2] A. Levitzki, European J. Cancer. 2002, 38, S11.

[3] M. W. Drummond, T. L. Holyoake, Blood Rev. 2001, 15, 85.

[4] D. Fabbro, D. Parkinson, A. Matter, Curr. Opin. Pharmacol. 2002, 2, 374.

[5] The Glivec International Site, http://www.glivec.com/about.

[6] D. Moffat, P. Davis, M. Hutchings, J. Davis, D. Berg, M. Batchelor, J. Johnson, J. O'Connell, R. Martin, T. Crabbe, J. Delgado, M. Perry, Bioorg. Med. Chem. Lett. 1999, 9, 3351.

[7] T. Schindler, W. Bornmann, P. Pellicena, W. T. Miller, B. Clarkson, J. Kuriyan, Science 2000, 289, 1938.

[8] J. A. Hickman, Curr. Opin. Gene. Develop. 2002, 12, 67.

[9] P. Zhang, W. Y. Gao, S. Turner, B. S. Ducatman, Mol. Cancer $2003,2,1$.

[10] J. Li, J. Kleeff, J. Guo, L. Fischer, N. Giese, M. W. Büchler, H. Friess, Mol. Cancer 2003, 2, 1.

[11] A. Czechowska, T. Poplawski, J. Drzewoski, J. Blasiak, Chem-Biol. Interact. 2005, 152, 139.

[12] E. Weisenberg, J. D. Griffin, Drug Resist. Updat. 2003, 6, 231.

[13] G. Hoser, I. Majsterek, D. L. Romana, A. Slupianek, J. Blasiak, T. Skorski, Leukem. Res. 2003, 27, 267.

[14] G. W. Krystal, Drug Resist. Updat. 2001, 4, 16.

[15] R. Bakhtiar, J. Lohne, L. Ramos, L. Khemani, M. Hayes, F. Tse, J. Chromatogr. B. 2002, 768, 325.

[16] R. A. Parise, R. K. Ramanathan, M. J. Hayes, M. J. Egorin, J. Chromatogr. B. 2003, 791, 39.

[17] R. Bakhtiar, L. Khemani, M. Hayes, T. Bedman, F. Tse, J. Pharm. Biomed. Anal. 2002, 28, 1183.

[18] G. Guetens, G. De Boeck, M. Highley, H. Dumez, A. T. Van Oosterom, E. A. de Bruijn, J. Chromatogr. A. 2003, 1020, 27. 
[19] D. Ivanovic, M. Medenica, B. Jancic, A. Malenovic, J. Chromatogr. B. 2004, 800, 253.

[20] J. R. Flores, J. J. Berzas, G. Castaneda, N. Rodriguez, J. Chromatogr. B. 2003, 794, 381.

[21] J. Rodriguez, J. J. Berzas, G. Castaneda, N. Rodriguez, Talanta 2005, 66, 202.

[22] V. C. Diculescu, J. A.P. Piedade, A. M. Oliveira Brett, Bioelectrochemistry 2006, in press.

[23] S. A. Özkan, B. Uslu, P. Zuman, Anal. Chim. Acta 2004, 501, 227.

[24] A. M. Oliveira Brett, M-E. Ghica, Electroanalysis 2003, 15, 1.
[25] A. M. Oliveira Brett, J. A.P. Piedade, L. A. da Silva, V. C. Diculescu, Anal. Biochem. 2004, 332, 321.

[26] E. Laviron, Electroanal. Chem. 1974, 52, 355.

[27] E. Laviron, R. M. Prest, R. Lacasse, J. Electroanal. Chem. 1994, 375, 236.

[28] J. Osteryoung, R. Osteryoung, Anal. Chem. 1985, 57, 101A.

[29] C. M. A. Brett, A. M. Oliveira Brett, Electrochemistry: Principles, Methods and Applications, Oxford University Press, Oxford 1993.

[30] http://www.hbcpnetbase.com/, Handbook of Chemistry and Physics.

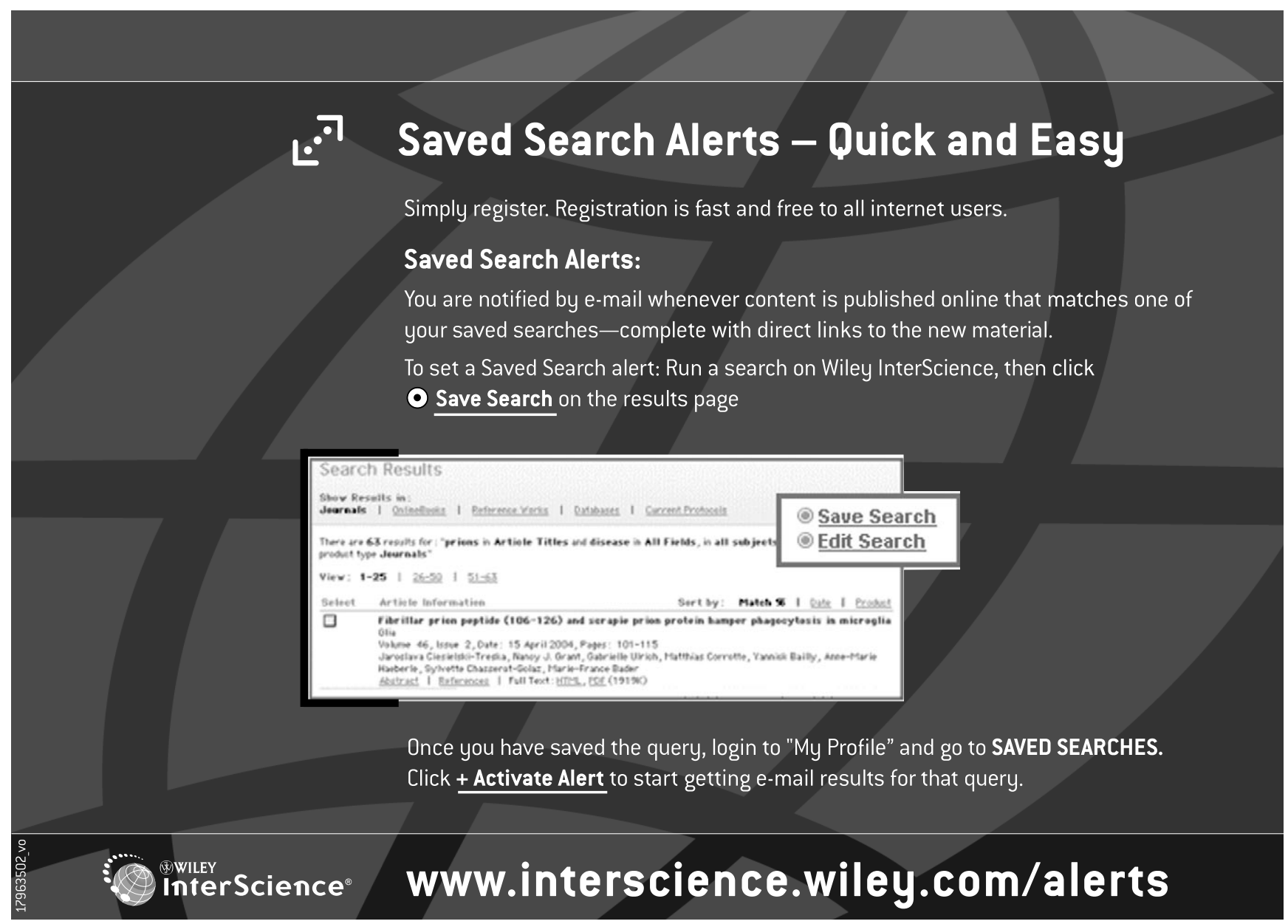

Electroanalysis 18, 2006, No. 18, 1800-1807 www.electroanalysis.wiley-vch.de @ 2006 WILEY-VCH Verlag GmbH \& Co. KGaA, Weinheim 